\title{
PERANCANGAN APLIKASI PEMILIHAN UMUM BERBASIS MOBILE ANDROID MENGGUNAKAN DATABASE BACKENDLESS
}

\author{
Cecep Mulyana Dipraja \\ Universitas Adhirajasa Reswara Sanjaya \\ e-mail: mulyanadipraja1994@gmail.com
}

\begin{abstract}
Abstrak
Pemilihan umum (Pemilu) merupakan sarana bagi masyarakat untuk ikut berpartisipasi dalam memberikan suaranya dalam memilih wakil rakyat. Lebih lanjut pemilu merupakan bukti adanya upaya untuk mewujudkan demokrasi. Sistem electronic voting (e-voting) dapat dimanfaatkan untuk membantu mempercepat proses pemungutan dan perhitungan suara. Salah satu teknologi yang dapat di manfaatkan untuk proses e-voting adalah perangkat smartphone android. Tujuan dari penulisan adalah merancang sistem e-voting berbasis mobile, menggunakan bahasa pemograman Java pada Android Studio serta database backendless dalam pengelolaan otentifikasi hak akses peserta. Sistem e-voting dapat menjadi alternative pengganti sistem pemilu konvensional, sehingga dapat digunakan oleh KPU untuk mempercepat proses pemungutan dan perhitungan suara di tempat pemungutan suara (TPS).
\end{abstract}

Kata Kunci: Aplikasi, E-Voting, Pemilu, Android, Backendless.

\begin{abstract}
Elections (Elections) are a means for the community to participate in voting in electing people's representatives. Furthermore, the election is evidence of efforts to realize democracy. Electronic voting (e-voting) systems can be utilized to help speed up the voting and counting process. One technology that can be utilized for the e-voting process is an Android smartphone device. The purpose of writing is to design a mobile-based e-voting system, using the Java programming language on Android Studio as well as a backendless database in managing authentication of participant access rights. The e-voting system can be an alternative to the conventional electoral system so that it can be used by the KPU to speed up the voting and counting process at the polling stations (TPS).
\end{abstract}

Keywords: Application, E-Voting, Election, Android, Backendless

\section{Pendahuluan}

Demokrasi mengandung makna bahwa kekuasaan tertinggi berada di tangan rakyat. Pemilu merupakan sebuah wadah untuk mewujudkan proses demokrasi dalam sebuah negara. Menurut (Labolo \& Ilham, 2015) "Pemilihan umum merupakan suatu sarana bagi masyarakat untuk ikut berpartisipasi dalam memberikan suaranya guna memilih wakil rakyat, serta merupakan bukti adanya upaya untuk mewujudkan demokrasi". Salah satu tolak ukur berjalannya demokrasi di Indonesia adalah adanya pelaksanaan Pemilihan Umum (Pemilu) untuk memilih Presiden dan Wakil Presiden, yang diadakan setiap 5 (lima) tahun sekali.

Menurut (Labolo \& Ilham, 2015) tujuan penyelenggaraan pemilu ada 4 (empat):
1. Untuk memungkinkan terjadinya peralihan kepemimpinan pemerintahan secara tertib dan damai.

2. Untuk memungkinkan akan adanya pergantian pejabat yang nantinya mewakili kepentingan masyarakyat di lembaga perwakilan.

3. Untuk melaksanakan prinsip kedaulatan rakyat di lembaga perwakilan.

4. Untuk melaksanakan prinsip hak-hak asasi warga negara.

Dalam pelaksanaan pemilu serentak yang diadakan oleh Komisi Pemilihan Umum (KPU) pada tanggal 17 April 2019 silam mengakibatkan banyak sekali korban jiwa dari pihak panitia pemilu, akibat dari kelelahan dan kurangnya waktu untuk beristirahat pada saat menjalankan tugas 
sebagai petugas Kelompok Penyelenggara Pemungutan Suara (KPPS). Para calon pemilih harus mengantri untuk dapat mengikuti proses pemilihan umum. Menurut (Ary et al., 2018) "Persoalan antrian merupakan hal yang mendasari dari antrian untuk bisa mendapatkan pelayanan. Persoalan antrian ini disebabkan oleh banyaknya yang datang atau pelanggan yang ingin dilayani sedangkan jumlah pelayan terbatas".

Berbagai masalah tersebut dapat diatasi dengan memanfaatkan teknologi yaitu dengan menerapkan sistem electronic voting (e-voting). E-voting dapat dimanfaatkan untuk membantu dalam proses pemungutan suara dan proses perhitungan suara di Tepat Pemungutan Suara (TPS). Salah satu teknologi yang dapat di manfaatkan untuk menjalankan sistem e-voting adalah perangkat mobile android. Tool yang digunakan oleh penulis dalam pengembangan aplikasi e-voting ini adalah Android Studio.

Berdasarkan latar belakang masalah diatas, penulis tertarik untuk merancang aplikasi berbasis mobile yang dapat digunakan dalam proses e-voting Pemilihan Umum (Pemilu) di TPS. Penelitian dan perancangan atas kajian tersebut penulis tuangkan dengan judul "Perancangan Aplikasi Pemilihan Umum Berbasis Mobile Android Menggunakan Database Backendless" menggunakan tool Android Studio dengan bahasa pemograman Java dan menggunakan tambahan database Firebase sebagai tambahan proses Authentication.

Maksud dan tujuan dari penelitian ini adalah sebagai berikut:

1. Merancang sebuah system e-voting yang dapat digunakan untuk Pemilihan Umum (Pemilu) pada Tempat Pemungutan Suara (TPS), dan diharapkan dapat menggantikan system voting Pemilu konvensional, sehingga dapat mengurangi waktu proses pemungutan suara dan proses perhitungan hasil suara di TPS.

2. Mengimplementasikan system $e$ voting berbasis mobile menggunakan tool Android Studio dengan bahasa pemograman Java dan menggunakan database Backendless sebagai pengolah data dan proses authentication serta database Firebase sebagai tambahan proses authentication.
Adapun batasan masalah dalam pembuatan perangkat lunak ini supaya tidak menyimpang dari tujuan yaitu sebagai berikut:

1. Aplikasi pemilihan umum berbasis mobile android ini digunakan oleh para petugas KPPS untuk menggantikan metode voting konvensional pada saat diselenggarakan pemilihan umum di TPS.

2. Aplikasi hanya ditujukan kepada para calon pemilih yang sudah terdaftar dalam Daftar Pemilih Tetap (DPT) di dalam data KPU dengan syarat membawa E-KTP dan surat undangan memilih (C4) untuk dapat ikut berpartisipasi memberikan suara.

3. Input sistem e-voting menggunakan nomer identitas pada Kartu Tanda Penduduk (KTP) serta menggunakan sandi acak yang terdapat pada surat undangan memilih (C4) yang di berikan oleh KPU.

4. Aplikasi hanya diperuntukan untuk platform android.

5. Data dikelola oleh admin TPS, proses pengolahan data dan proses otentikasi hak masuk system menggunakan database Backendless dan database Firebase.

6. Sistem e-voting ini digunakan pada tingkat TPS untuk mempermudah proses pengolahan data di TPS. Untuk mekanisme kemanan data dapat dilakukan penelitian lebih lanjut yang melibatkan pakar - pakar ahli keamanan jaringan dalam pengiriman data, agar proses pemilihan umum menggunakan e-voting berbasis mobile android ini dapat diwujudkan dan terlaksana dengan baik.

7. Dalam simulasi e-voting ini menggunakan dua contoh TPS, dimana masing-masing TPS mempunyai empat akun admin TPS yang berbeda untuk bisa masuk ke dalam system e-voting, sehingga dapat digunakan perangkat smartphone mobile android yang berbeda, untuk dapat digunakan pada Pemilu empat bilik suara yang berbeda.

Pemilihan Umum (Pemilu) merupakan suatu wadah partisipasi masyarakat dalam mewujudkan proses demokrasi. Berdasarkan Undang-Undang Tahun 2011 No.15, Pemilihan Umum, selanjutnya disingkat 
Pemilu, adalah sarana pelaksanaan kedaulatan rakyat yang diselenggarakan secara langsung, umum, bebas, rahasia, jujur, dan adil dalam Negara Kesatuan Republik Indonesia berdasarkan Pancasila dan Undang-Undang Dasar Negara Republik Indonesia Tahun 1945.

\section{E-Voting}

Menurut (Shalahuddin, 2009) dalam (Sulastri \& Zulita, 2015) "E-voting adalah proses pemungutan suara yang memanfaatkan elektronik. Seiring dengan perkembangan zaman, sudah banyak penelitian pemanfaatan elektronik pada proses pemungutan suara yang menggantikan proses pemungutan suara secara manual, teknologi tersebut disebut $e$ voting".

Keamanan dan kerahasiaan data peserta e-voting dalam melakukan pemilihan harus terjaga dengan baik dengan adanya protokol keamanan sistem e-voting. Hal tersebut bertujuan untuk menjamin kerahasiaan data peserta e-voting dan keakuratan pilihan. Menurut (Canard \& Sibert, 2001) dalam (Sulastri \& Zulita, 2015) "Keamanan sistem ini memiliki beberapa kriteria yaitu:

1. Eligibility. Hanya pemilih yang terdaftar yang dapat melakukan pemilihan.

2. Unreusability. Setiap pemilih hanya bisa memberikan satu kali pilihan.

3. Anonymity. Pilihan pemilih dirahasiakan

4. Accuracy. Pilihan tidak bisa diubah atau dihapus selama atau setelah pemilihan dan juga tidak bisa ditambahkan setelah pemilihan ditutup.

5. Fairness. Perhitungan suara sebelum pemilihan ditutup tidak bisa dilakukan.

6. Vote and Go. Pemilih hanya dapat melakukan pemilihan saja.

7. Public Verifiability. Setiap orang dapat melakukan pengecekan pada berjalannya proses pemilihan"

\section{Smartphone}

Smartphone atau ponsel pintar merupakan jenis handphone dengan teknologi terbaru yang mempunyai fungsifungsi layaknya personal komputer atau laptop. Dengan segudang fitur layaknya personal computer, smartphone memiliki beberapa keunggulan diantaranya yaitu bentuk fisiknya yang relative lebih kecil sehingga mudah dibawa kemana-mana.

\section{Android}

Android merupakan sistem operasi untuk smart phone berbasis linux yang dibuat dan dikembangkan oleh Google. Android merupakan platform terbuka sehingga para pengembang bebas membangun aplikasi buatan mereka dan dijalankan pada sistem operasi Android.

Android Studio

Aplikasi yang akan dirancang dan dibangun pada penelitian ini adalah suatu aplikasi e-voting berbasis android yang akan dirancang menggunakan Android Studio. Android Studio merupakan Integrated Development Environment (IDE) resmi yang disediakan oleh Google untuk para pengembang aplikasi yang bersifat open source atau gratis untuk merancang dan membangun aplikasi berbasis android.

\section{Database}

Database (basis data) merupakan sekumpulan data yang saling berkaitan dan tersimpan untuk memenuhi berbagai kebutuhan pengguna. Dalam penelitian ini penulis menggunakan database backenless dan database firebase yang berfungsi untuk menyinkronkan data antara database dan device yang terhubung dengan cepat, sehingga user dapat menerima update data terbaru secara otomatis.

\section{Unified Modelling Language (UML)}

Unfiied Modelling Language (UML) digunakan untuk memberikan informasi gambaran setiap alur yang berjalan pada sistem. Menurut (Firmansyah, 2017) diagram UML memiliki tujuan utama untuk membantu tim pengembangan proyek berkomunikasi, mengeksplorasi potensi desain, dan memvalidasi desain arsitektur perangkat lunak atau pembuat program. meliputi:

UML yang dipakai oleh penulis

\section{Use Case Diagram}

Use case diagram mendeskripsikan sebuah interaksi antara satu atau lebih aktor dengan sistem informasi yang akan dibuat.

\section{Activity Diagram}

Activity diagram memberikan informasi bagaimana tahapan alur dari suatu sistem yang sedang dibuat, bagaimana alur tersebut berawal, keputusan dan pilihan apa saja yang tersedia pada sistem, dan bagaimana alur tersebut berakhir.

\section{Sequence Diagram}

Sequence diagram memberikan informasi bagaimana tindakan objek pada use case dengan mendeskripsikan alur dan 
pesan yang dikirimkan dan diterima antar objek

\section{Metode Penelitian \\ Metode Pengumpulan Data}

Metode pengumpulan data yang digunakan oleh penulis dalam penelitian ini, antara lain:

1. Studi Literatur

Studi literatur yang digunakan yaitu jurnal, buku-buku, dan internet yang menyajikan informasi tentang android studio, android, pemilihan umum, e-voting, bahasa pemrograman Java, database backendless dan database firebase.

2. Observasi

Observasi dilakukan dengan melakukan pengamatan secara langsung pada saat proses Pemilihan Umum di TPS untuk memperoleh informasi yang diperlukan.

\section{Sumber Data}

Sumber data pada penelitian ini dilakukan dengan cara mengumpulkan data dari beberapa buku, jurnal, skripsi maupun literatur yang berkaitan dengan android studio, android, pemilihan umum, e-voting, bahasa pemrograman Java, database backendless dan database firebase sebagai objek penelitian.

\section{Analisa Kebutuhan}

a. Analisa Kebutuhan Perangkat Keras Untuk mendukung proses perancangan dan pengembangan dari sistem aplikasi dalam penelitian ini menggunakan spesifikasi perangkat keras sebagai berikut ini:

1) Smartphone Android Vivo Y95 (4GB/64GB)

2) Laptop Acer Aspire 4745G

Adapun spesifikasi laptop yang digunakan adalah sebagai berikut:

1) Processor Intel(R) Core(TM) i5 M460 $@ 2,53 \mathrm{Ghz}$

2) RAM 6GB DDR3

3) Harddisk Seagate 1TB + SSD V-Gen 120GB

4) Display 14 inch

b. Analisa Kebutuhan Perangkat Lunak Kebutuhan perangkat luak (software) yang digunakan dalam penelitian ini meliputi:

1) Sistem Operasi Windows 10 Education 64-bit

2) Android Studio versi 3.6.1

3) SDK (Software Development Kit )

4) JDK (Java Development Kit)

5) Web Browser (Google Chrome)

6) Microsoft Visio 2013
7) Adobe Photoshop CS 5

8) Microsoft Office 2016

Perancangan Alur Halaman Aplikasi

Dalam perancangan dan pembuatan aplikasi pemilihan umum berbasis mobile android menggunakan database backendless terdapat beberapa elemen pembangun utama yang diaplikasikan pada software yang dibangun, antara lain:

1. Halaman masuk akun TPS

2. Halaman masuk akun voting

3. Halaman voting (tampilan calon Presiden dan calon Wakil Presiden)

4. Halaman konfirmasi kandidat yang dipilih

5. Halaman masuk admin TPS untuk melihat hasil perolehan suara

\section{Perancangan Alur Sistem Database}

Pada perancangan database penulis menggunakan dua jenis database, yaitu database firebase dan database backendless sebagai database utama pengolahan data.

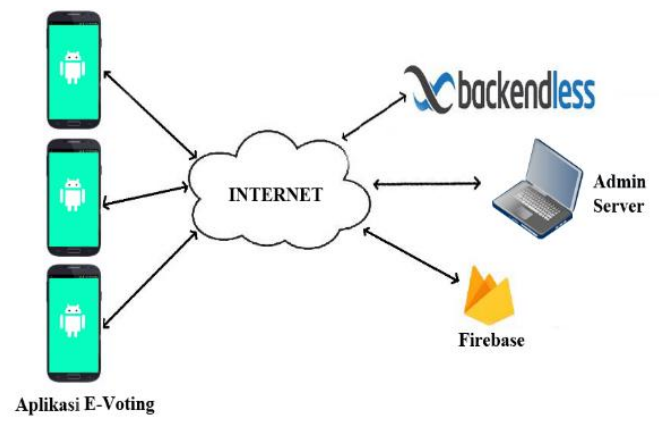

Gambar 1 Alur Sistem Database

1. Database Firebase

Database firebase digunakan oleh penulis untuk proses pemeriksaan hak akses masuk akun TPS. Seluruh akun TPS yang terdaftar pada proses e-voting tersimpan di dalam database firebase, sebagai user. Akun TPS tersebut memiliki ID TPS dan Password yang berbeda-beda yang dapat digunakan oleh masing-masing TPS untuk proses masuk ke dalam aplikasi e-voting pemilihan umum. Tanpa memiliki ID TPS dan Password maka aplikasi e-voting ini tidak dapat digunakan, karena aplikasi e-voting ini dirancang untuk digunakan oleh petugas TPS sehingga dapat mempermudah proses pemungutan suara dan perhitungan suara. Seluruh proses penambahan, pengubahan, dan penghapusan data akun TPS pada database firebase hanya dikelola oleh Admin Server sebagai pusat pengelola database.

2. Database Backendless Setelah petugas TPS berhasil masuk 
ke dalam aplikasi e-voting menggunakan akun TPS, maka aplikasi e-voting mulai dapat digunakan untuk melakukan proses pemungutan suara dengan memilih tombol voting. Langkah selanjutnya untuk dapat ikut berpartisipasi memberikan hak suara pada aplikasi e-voting adalah dengan memasukan data akun voting dengan memasukan Nomor Induk Kependudukan (NIK) dan ID Daftar Pemilih Tetap (DPT) yang sudah terdaftar sebagai user di dalam database backendless. Para calon pemilih harus membawa dan memberikan E-KTP dan surat undangan memilih (C4) kepada petugas TPS untuk proses verifikasi data. Nomor Induk Kependudukan diperoleh dari E-KTP, dan ID Daftar Pemilih Tetap dipeoleh dari surat undangan memilih. Seluruh proses penambahan, pengubahan, dan penghapusan data akun voting pada database backenless hanya dikelola oleh Admin Server sebagai pusat pengelola database. Di dalam data user akun voting terdapat data NIK, password, nama pemilih, tanggal lahir, dan status memilih yang memberikan informasi apakah akun voting tersebut sudah digunakan untuk melakukan pemilihan atau belum.

Selanjutanya di dalam database backendless terdapat tabel Paslon yang berisi data pasangan calon presiden, calon wakil presiden, nomor urut, dan jumlah suara yang diperoleh. Tabel Paslon ini selain berguna untuk menampilkan informasi pasangan calon, juga berfungsi untuk melakukan perekapan data hasil voting dan menampilkan total jumlah perolehan suara yang diperoleh oleh masing-masing pasangan calon.

Perancangan UML

1. Use Case Diagram

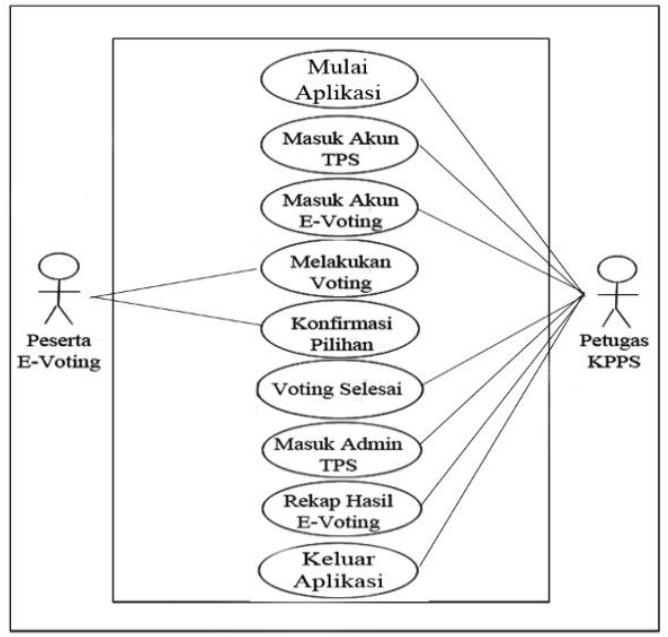

Gambar 2 Use Case Diagram a. Peserta E-Voting adalah seluruh peserta yang sudah terdaftar dan berhak mengikuti proses pemilihan umum.

b. Petugas KPPS adalah petugas admin yang bertugas di tempat pemungutan suara (TPS) yang mengatur seluruh proses pemilihan umum di TPS.

c. Petugas KPPS mulai membuka dan menjalakan aplikasi e-voting.

d. Petugas KPPS memasukan ID TPS dan Password yang didapatkan dari Admin Server Pusat untuk dapat masuk ke dalam aplikasi e-voting sebagai identifikasi akun TPS.

e. Untuk dapat mengikuti proses e-voting maka calon peserta e-voting harus masuk ke dalam akun voting menggunakan NIK dan ID DPT. Petugas KPPS membantu memasukan NIK dan ID DPT yang berasal dari E-KTP dan surat undangan memilih (C4) yang diserahkan oleh calon peserta e-voting yang sudah melewati proses verifikasi oleh petugas KPPS.

f. Peserta E-Voting melakukan proses voting di bilik suara dengan menentukan pilihan pasangan calon yang dipilih dan menekan gambar pasangan calon mana yang dipilih.

g. Peserta E-Voting mengkonfirmasi pasangan calon yang dipilih dan menekan tombol KIRIM.

h. Halaman voting tertutup otomatis oleh sistem aplikasi apabila data sudah berhasil dikirim, dan aplikasi akan kembali ke halaman masuk akun voting untuk calon peserta lain yang belum memilih.

i. Setelah seluruh Peserta E-Voting selesai menentukan pasangan calon yang dipilihnya, petugas KPPS masuk ke dalam Admin TPS dengan memasukan kembali ID TPS dan Password untuk melakukan perekapan data.

j. Petugas KPPS merekap seluruh hasil perolehan suara masing-masing pasangan calon dengan menekan tombol PEROLEHAN SUARA.

k. Petugas KPPS menekan tombol KELUAR AKUN TPS untuk keluar dari akun TPS, dan menekan tombol KELUAR APLIKASI untuk keluar dan mengakhiri aplikasi e-voting. 
2. Activity Diagram

Berikut adalah activity diagram dari aplikasi pemilihan umum berbasis mobile android yang dibangun:

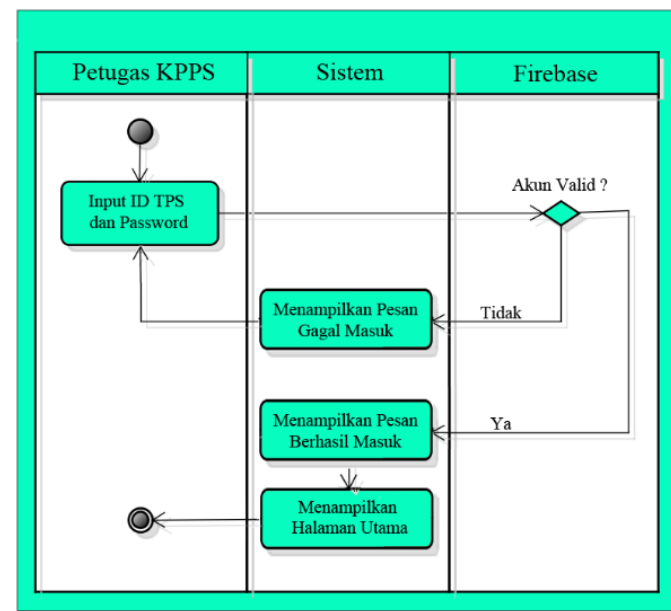

Gambar 3 Diagram Aktivitas Masuk Akun TPS

Gambar 3 merupakan aktivitas untuk proses pemeriksaan hak akses masuk ke dalam akun TPS. Aktivitas ini dimulai dengan petugas KPPS memasukan ID TPS dan Password yang didapatkan dari Admin Server Pusat. Dalam tahap ini, sistem akan melakukan pemeriksaan ID TPS dan Password yang dimasukan apakah sudah sesuai atau tidak dengan akun TPS yang sudah terdaftar di dalam database Firebase. Apabila ID TPS atau Password tidak sesuai atau tidak terdaftar di dalam database akun TPS, maka sistem akan menampilkan pesan 'Gagal Masuk Akun TPS' dan diarahkan untuk kembali mengisi ID TPS dan Password dengan benar. Apabila ID TPS dan Password sudah sesuai dengan akun TPS yang terdaftar di dalam database, maka sistem akan menampilkan pesan 'Berhasil Masuk Akun TPS' dan akan menampilkan halaman utama.

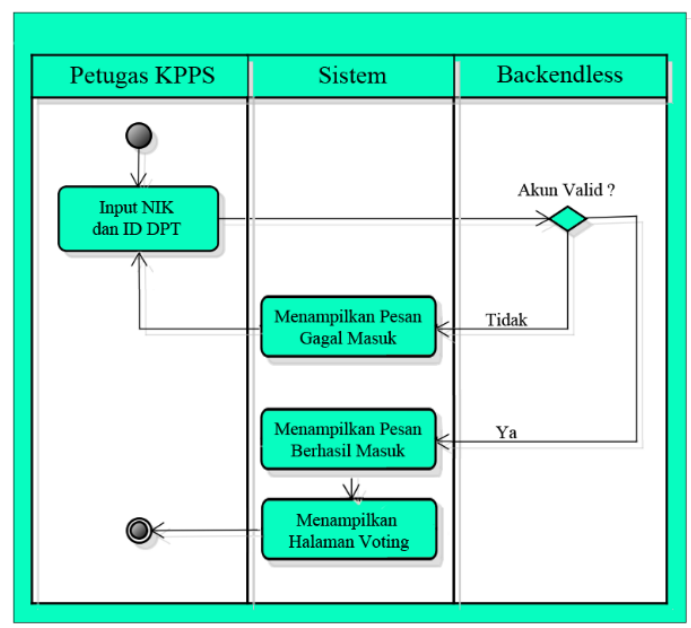

Gambar 4 Diagram Aktivitas Masuk Akun Voting Gambar 4 merupakan aktivitas untuk proses pemeriksaan hak akses masuk ke dalam akun voting. Aktivitas ini dimulai dengan petugas KPPS memasukan Nomor Induk Kependudukan (NIK) dan ID Daftar Pemilih Tetap (DPT) sesuai E-KTP dan surat undangan memilih (C4) yang diserahkan oleh calon peserta e-voting. Dalam tahap ini, sistem akan melakukan pemeriksaan NIK dan ID DPT yang dimasukan apakah sudah sesuai atau tidak dengan akun voting yang sudah terdaftar di dalam database backendless. Apabila NIK atau ID DPT tidak sesuai atau tidak terdaftar di dalam database, maka sistem akan menampilkan pesan 'Gagal Masuk Akun Voting' dan diarahkan untuk kembali mengisi NIK dan ID DPT dengan benar. Apabila NIK dan ID DPT sudah sesuai dengan akun voting yang terdaftar di dalam database, maka sistem akan menampilkan pesan 'Berhasil Masuk Akun Voting' dan sistem akan menampilkan halaman voting.

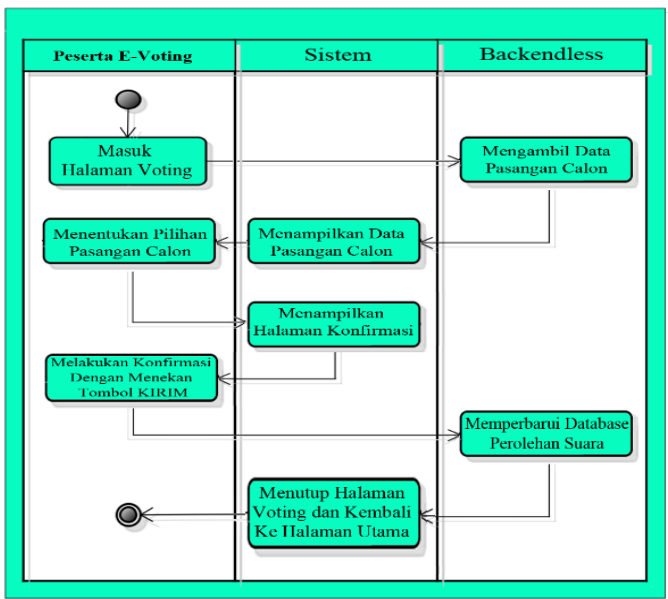

Gambar 5 Diagram Aktivitas Proses Voting

Gambar 5 merupakan aktivitas untuk proses voting. Aktivitas ini dimulai dengan masuk ke halaman voting. Kemudian sistem akan mengambil data daftar pasangan calon yang tersimpan di dalam database backendless, selanjutnya sistem menampilkan data pasangan calon tersebut di halaman voting. Tahap selanjutnya peserta e-voting menentukan pilihan pasangan calon yang diinginkan dengan menekan gambar pasangan calon yang dipilih. Kemudian sistem akan menampilkan halaman konfirmasi data pasangan calon yang dipilih. Selanjutnya peserta e-voting menekan tombol KIRIM untuk mengkonfirmasi pasangan calon yang telah dipilih tersebut. Selanjutnya sistem akan 
mengirim data pilihan pasangan calon tersebut ke dalam database backendless dan memperbarui data jumlah perolehan suara pasangan calon yang dipilih di dalam database. Selanjutnya sistem akan menampilkan pesan "PILIHAN ANDA BERHASIL DIKIRIM..TERIMAKASIH" kemudian sistem akan menutup otomatis halaman voting, dan kembali ke halaman utama.

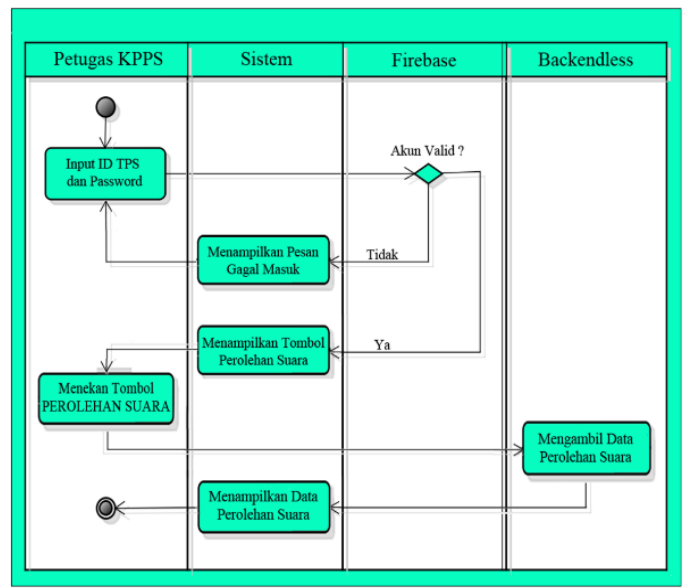

Gambar 6 Diagram Aktivitas Rekap Perolehan Suara

Gambar 6 merupakan aktivitas untuk proses perekapan data hasil perolehan suara dari masing-masing pasangan calon oleh petugas KPPS ketika proses voting sudah selesai diselenggarakan. Aktivitas ini dimulai dengan petugas KPPS menekan tombol MASUK ADMIN TPS pada halaman utama, kemudian memasukan ID TPS dan Password. Sama seperti proses masuk akun TPS, selanjtnya sistem akan melakukan pemeriksaan ID TPS dan Password yang dimasukan apakah sudah sesuai atau tidak dengan akun TPS yang sudah terdaftar di dalam database Firebase. Apabila ID TPS atau Password tidak sesuai atau tidak terdaftar di dalam database akun TPS, maka sistem akan menampilkan pesan 'Gagal Masuk' dan diarahkan untuk kembali mengisi ID TPS dan Password dengan benar. Apabila ID TPS dan Password sudah sesuai dengan akun TPS yang terdaftar di dalam database, maka sistem akan menampilkan pesan 'Berhasil Masuk Admin TPS' dan akan menampilkan tombol PEROLEHAN SUARA. Selanjutnya petugas menekan tombol PEROLEHAN SUARA tersebut, maka sistem akan mengambil data jumlah perolehan suara masing-masing pasangan calon yang tersimpan di dalam database backendless dan menampilkannya pada halaman PEROLEHAN SUARA.
3. Sequence Diagram

Berikut ini merupakan sequence diagram dari aplikasi pemilihan umum berbasis mobile android yang dibangun:

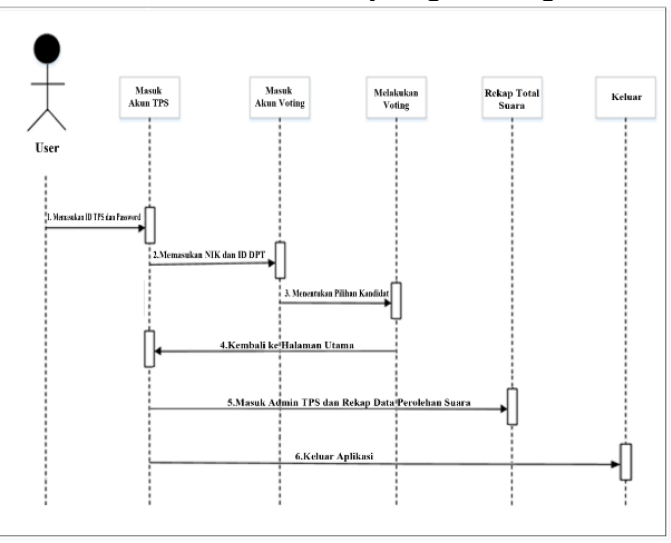

Gambar 7 Diagram Sekuensial Aplikasi Pemilihan Umum

Gambar 7 di atas menunjukkan diagram sekuensial untuk aplikasi pemilihan umum berbasis mobile android. Tedapat enam proses utama, yaitu masuk akun TPS dengan memasukan ID TPS dan Password, masuk akun voting dengan memasukan NIK dan ID DPT, melakukan voting dengan menentukan pilihan kandidat pasangan calon, sistem kembali ke halaman utama, masuk Admin TPS dengan memasukan ID TPS dan Password dan melakukan rekap data total perolehan suara, dan proses terakhir adalah keluar dari aplikasi.

\section{Hasil dan Pembahasan}

\section{Halaman Masuk Akun TPS}

Petugas KPPS memasukan ID TPS dan Password yang didapatkan dari Admin Server Pusat untuk dapat masuk ke dalam aplikasi e-voting sebagai identifikasi akun TPS. Tampilan halaman masuk akun TPS pada perangkat smartphone android akan terlihat seperti pada Gambar 8 di bawah ini:

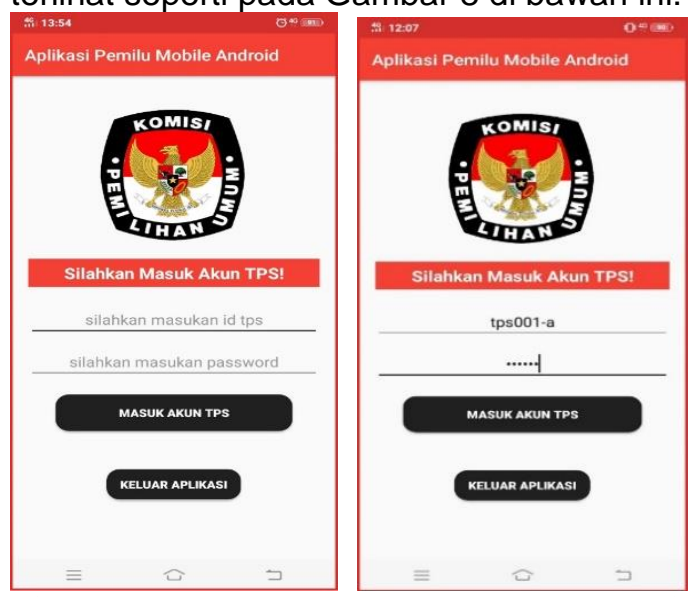

Gambar 8 Tampilan Halaman Masuk Akun TPS 
Setelah petugas KPPS memasukan ID TPS dan Password, kemudian menekan tombol 'MASUK AKUN TPS', selanjutnya sistem akan melakukan pemeriksaan ID TPS dan Password yang dimasukan apakah sudah sesuai atau tidak dengan akun TPS yang sudah terdaftar di dalam database Firebase.

Apabila ID TPS atau Password tidak sesuai atau tidak terdaftar di dalam database akun TPS, maka sistem akan menampilkan pesan 'Gagal Masuk Akun TPS' dan diarahkan untuk kembali mengisi ID TPS dan Password dengan benar.

Apabila ID TPS dan Password sudah sesuai dengan akun TPS yang terdaftar di dalam database akun TPS, maka sistem akan menampilkan pesan 'Berhasil Masuk Akun TPS' dan akan menampilkan halaman utama

\section{Halaman Masuk Akun Voting}

Setelah berada pada halaman utama, selanjutnya petugas KPPS menekan tombol 'VOTING' untuk masuk ke halaman identifikasi masuk akun voting. Petugas KPPS membantu memasukan Nomor Induk Kependudukan (NIK) dan ID Daftar Pemilih Tetap (DPT) sesuai E-KTP dan surat undangan memilih (C4) yang diserahkan oleh calon peserta e-voting sebagai identifikasi akun voting tersebut. Tampilan halaman masuk akun voting pada perangkat smartphone android akan terlihat seperti pada Gambar 9 di bawah ini:

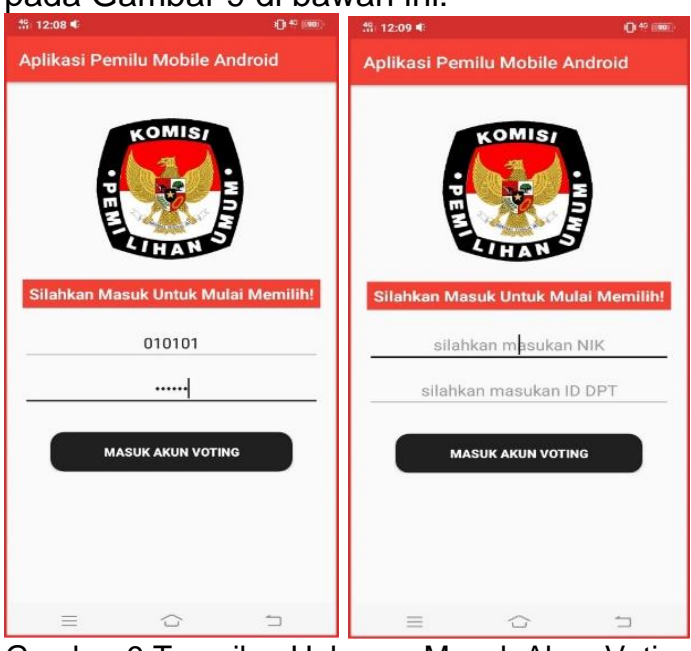

Gambar 9 Tampilan Halaman Masuk Akun Voting

Setelah petugas KPPS memasukan NIK dan ID DPT, kemudian menekan tombol 'MASUK AKUN VOTING' selanjutnya sistem akan melakukan pemeriksaan NIK dan ID DPT yang dimasukan apakah sudah sesuai atau tidak dengan akun voting yang sudah terdaftar di dalam database backendless.

Apabila NIK atau ID DPT tidak sesuai atau tidak terdaftar di dalam database akun voting, maka sistem akan menampilkan pesan 'Gagal Masuk Akun Voting' dan diarahkan untuk kembali mengisi NIK dan ID DPT dengan benar.

Apabila NIK dan ID DPT sudah sesuai dengan akun voting yang terdaftar di dalam database akun voting, maka sistem akan menampilkan pesan 'Berhasil Masuk Akun Voting' dan akan menampilkan halaman voting.

Untuk mencegah kecurangan, maka satu akun voting hanya dapat digunakan satu kali dalam memberikan suara, sehingga apabila terdapat akun voting yang sudah memilih, kemudian mencoba masuk kembali ke halaman voting dengan memasukan NIK dan ID DPT yang sama, maka sistem akan menolak secara otomatis dan mengembalikan ke halaman utama.

\section{Halaman Voting}

Setelah berhasil masuk ke dalam akun voting, sistem akan mengambil data daftar pasangan calon yang tersimpan di dalam database backendless, selanjutnya sistem menampilkan data pasangan calon tersebut di halaman voting. Tahap selanjutnya peserta e-voting melakukan proses voting di bilik suara yang sudah disediakan, untuk menjaga kerahasiaan pilihan peserta tersebut. Peserta menentukan pilihan pasangan calon yang diinginkan dengan menekan gambar pasangan calon mana yang dipilih. Tampilan halaman voting pada perangkat smartphone android akan terlihat seperti pada Gambar IV.25 di bawah ini:

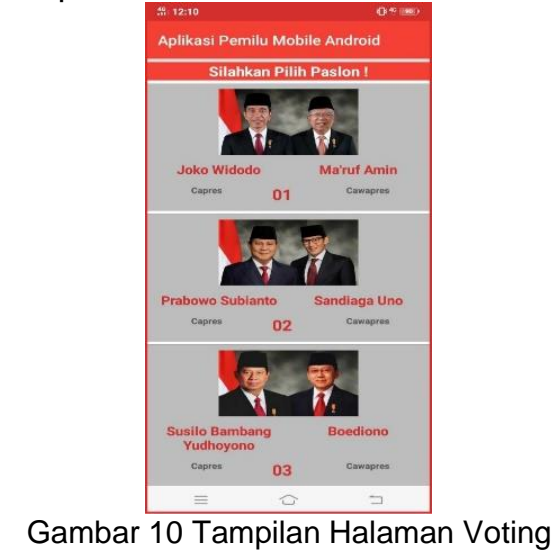

\section{Halaman Konfirmasi Kandidat}

Setelah peserta e-voting menentukan pilihan pasangan calon yang dipilih, selanjutnya sistem akan menampilkan 
halaman konfirmasi kandidat pasangan calon yang dipilih, di dalam halaman tersebut sistem menampilkan nama pasangan calon dan nomor urut pasangan calon yang dipilih oleh peserta e-voting. Tampilan halaman konfirmasi kandidat pasangan calon pada perangkat smartphone android akan terlihat seperti pada Gambar 11 di bawah ini:

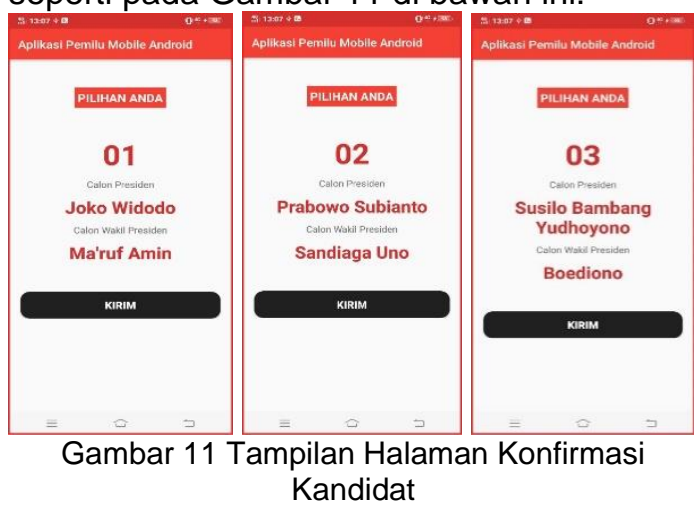

Halaman konfirmasi kandidat akan menampilkan salah satu tampilan dari Gambar 11 di atas, tergantung dari pasangan calon mana yang dipilih oleh peserta evoting. Setelah yakin dengan pilihannya maka peseta e-voting dapat mengirim data pilihannya tersebut dengan menekan tombol 'KIRIM'. Selanjutnya sistem akan mengirim data pilihan tersebut ke dalam database backendless.

Setelah data berhasil dikirim ke database backendless, maka sistem akan menampilkan pesan "Berhasil Memilih!", "Pilihan Anda berhasil dikirim Terimakasih!". Kemudian sistem akan menutup halaman voting secara otomatis dan akan menampilkan halaman utama kembali untuk proses voting peserta e-voting selanjutnya.

\section{Halaman Hasil Perolehan Suara}

Setelah seluruh peserta e-voting berhasil menyelesaikan proses voting, maka langkah selanjutnya untuk petugas KPPS adalah merekap hasil perolehan suara masing-masing pasangan calon. Pada halaman utama, petugas menekan tombol 'MASUK ADMIN TPS', kemudian sistem akan menampilkan halaman masuk Admin TPS. Pada halaman ini petugas memasukan kembail ID TPS dan Password seperti langkah pada Halaman Masuk Akun TPS. Setelah berhasil masuk Admin TPS maka sistem akan menampilkan tombol 'PEROLEHAN SUARA'

Langkah selanjutnya petugas KPPS menekan tombol 'PEROLEHAN SUARA' untuk memuat data perolehan suara masing- masing pasangan calon dari database backendless

Setelah data berhasil dimuat dari database backendless, maka sistem akan menampilkan data perolehan suara tersebut pada halaman perolehan suara. Tampilan halaman perolehan suara pada perangkat smartphone android tersebut akan terlihat seperti pada Gambar 12 di bawah ini:

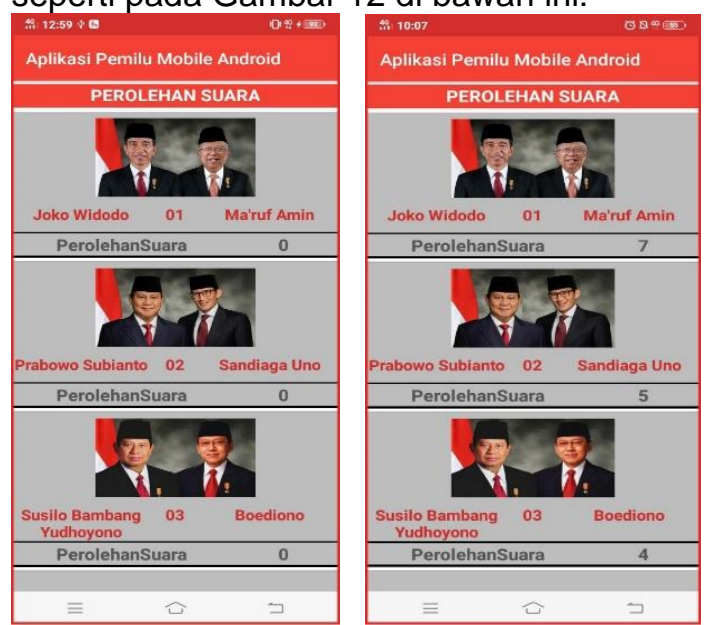

Gambar 12 Tampilan Halaman Perolehan Suara

Pada Gambar IV.33 sebelah kiri di atas terlihat hasil perolehan suara 0 (nol) adalah contoh tampilan halaman perolehan suara sebelum proses e-voting diselenggarakan, sedangkan sebelah kanan adalah contoh tampilan halaman perolehan suara dengan perancangan jumlah peserta e-voting 16 (enam belas) peserta. Pada proses e-voting yang sesungguhnya, jumlah peserta e-voting dapat diatur pada pendaftaran peserta evoting database backendless sesuai dengan kebutuhan peserta yang diperlukan.

\section{Kesimpulan}

Berdasar kegiatan yang telah dilakukan oleh penulis selama perancangan dan pembuatan aplikasi pemilihan umum berbasis mobile android, maka dapat diambil beberapa kesimpulan berikut:

1. Aplikasi pemilihan umum berbasis mobile android ini dapat menjadi metode alternative untuk digunakan oleh para petugas KPPS untuk dapat mengurangi waktu pemungutan suara dan waktu perhitungan hasil suara di TPS.

2. Aplikasi pemilihan umum berbasis mobile android dibangun dengan bahasa pemrograman Java pada Android Studio, serta memanfaatkan database firebase untuk mengelola akun TPS dan database backendless untuk mengelola akun 
peserta e-voting dan pengelolaan data perolehan suara pasangan calon.

3. Sistem aplikasi pemilihan umum berbasis mobile android ini tidak terlepas dari kekurangan dan kelemahan. Perlu diadakan penelitian lanjutan untuk memperkuat keamanan data dan pengembangan sistem aplikasi yang lebih efektif dan lebih baik lagi.

\section{Referensi}

Ary, M. (2018). Pendekatan Teori Antrian Single Channel Single Phase Pada Pelayanan Administrasi. Infotronik: Jurnal Teknologi Informasi dan Elektronika, 3(1), 21-27.

Firmansyah, R. (2017). Web Klarifikasi Berita Untuk Meminimalisir Penyebaran Berita Hoax. Jurnal Informatika, 4(2).

Labolo, M., \& Ilham, T. (2015). Partai Politik dan Sistem Pemilihan Umum di Indonesia. Rajawali Pers.

Shalahuddin, M. (2009). Pembuatan Model E-Voting Berbasis Web (Studi Kasus PEMILU Legislatif Dan Presiden Indonesia). Diambil dari: https://digilib. dinus. ac. id/2013/03/prosal-tesis7. pdf (25 Januari 2017).

Sulastri, \& Zulita, L. N. (2015). E- Votting Pemilihan Walikota Bengkulu Di Komisi Pemilihan Umum (Kpu) Kota Bengkulu. Jurnal Media Infotama, 11(2), 181-190. https://jurnal.unived.ac.id/index.php/jmi /article/view/265 